\title{
Pengaruh Sistem Pengupahan terhadap Kinerja Dosen Swasta di Propinsi Riau
}

\author{
AFRIJAL \\ Fakultas Ekonomi Universitas Pasir Pengaraian \\ Pasir Pengaraian \\ E-mail : afrijal_ak@yahoo.com
}

\begin{abstract}
The purpose of this study was to determine the effect of influence of compensation on the performance of the lecturer of private college lecturer in Riau province. The whole object of research lecturer in Private University in three colleges namely Riau Islamic University (UIR), Lancang Kuning University (UNILAK) and the University of sand Pengaraian (UPP) at the Faculty of Economics and Management Studies Program Akuntasni totaling 68 people consisting of as many UIR 31 people, 25 and UPP UNILAK as many as 12 people with saturated sampling technique. The method used in this study is a quantitative method. The results showed that the compensation to the performance of 0,160 professors
\end{abstract}

Keywords: compensation, performance of the lecturer.

Riau adalah sebuah provinsi di Indonesia. Provinsi ini terletak di Pulau Sumatra dan beribukotakan Pekanbaru. Provinsi Riau di sebelah utara berbatasan dengan Kepulauan Riau dan Selat Melaka; di sebelah selatan dengan Provinsi Jambi dan Selat Berhala; di sebelah timur berbatasan dengan Laut Cina Selatan (Provinsi Kepulauan Riau), dan di sebelah barat berbatasan dengan Provinsi Sumatera Barat dan Provinsi Sumatera Utara.

Riau kaya akan sumber daya alam, baik kekayaan yang terkandung di perut bumi, berupa minyak dan gas bumi, emas, dll. maupun kekayaan hutan dan perkebunannya, belum lagi kekayaan sungai dan lautnya. Seiring otonomi daerah, kekayaan tersebut bertahap mulai disalurkan secara penuh ke daerah (tidak sepenuhnya diberikan ke pusat) lagi. Aturan baru dari pemerintahan reformasi, memberi batasan dan aturan tegas mengenai kewajiban penanam modal, pemanfaatan sumber daya dan bagi hasil dengan lingkungan sekitar.

Suku bangsa: Suku Melayu, Suku Jawa, Suku Minangkabau, Suku Batak, Suku Banjar, Suku Tionghoa, Suku Bugis, Suku Sunda. Bahasa: Bahasa Indonesia, Bahasa Melayu, Bahasa Minangkabau.
Agama: Islam, Kristen Protestan, Kristen Katolik, Hindu, Buddha, Konghucu.

Riau mempunyai beberapa perguruan tinggi, seperti perguruan tinggi negeri seperti : Universitas Riau, Universitas Islam Negri SUSKA (Sultan Syarif Kasim) dan Perguruan Tinggi Swasta seperti: Universitas Islam Riau, Universitas Lancang Kuning, Universitas Muhammadiyah Riau, Universitas Abdurab, Universitas Pasir Pengaraian dan Universitas Islam Indragiri. Selain itu juga terdapat Politeknik Caltex Riau, dan Lembaga pendidikan dan pelatihan setingkat sekolah tinggi dan akademi.

Berdasarkan data, maka dapat diketahui bahwa jumlah terbesar mahasiswa di UIR dan diikuti dengan UNILAK dan UNISI serta UMRI, UNIRAB dan UPP.

Perguruan Tinggi adalah pusat penyelenggaraan dan pembangunan ilmu pengetahuan, teknologi dan kesenian, sebagai masyarakat ilmiah yang penuh citacita luhur, guna melaksanakan kehidupan berbangsa dalam rangka mencapai tujuan pendidikan nasional sebagaimana tercantum dalam pembukaan UUD 1945.

Dosen adalah pendidik profesional dan ilmuwan dengan tugas utama 
mentransformasikan, mengembangkan, dan menyebarluaskan ilmu pengetahuan, teknologi, dan seni melalui pendidikan, penelitian, dan pengabdian kepada masyarakat. Profesi dosen merupakan bidang pekerjaan khusus yang dilaksanakan berdasarkan prinsip sebagai berikut: Memiliki bakat, minat, panggilan jiwa, dan idealisme; Memiliki komitmen untuk meningkatkan mutu pendidikan, keimanan, ketakwaan, dan akhlak mulia; Memiliki kualifikasi akademik dan latar belakang pendidikan sesuai dengan bidang tugas; Memiliki kompetensi yang diperlukan sesuai dengan bidang tugas; Memiliki tanggung jawab atas pelaksanaan tugas keprofesionalan; Memperoleh penghasilan yang ditentukan sesuai dengan prestasi kerja; Memiliki kesempatan untuk mengembangkan keprofesionalan secara berkelanjutan dengan belajar sepanjang hayat; Memiliki jaminan perlindungan hukum dalam melaksanakan tugas keprofesionalan; Dosen wajib memiliki kualifikasi akademik, kompetensi, sertifikat pendidik, sehat jasmani dan rohani, dan memenuhi kualifikasi lain yang dipersyaratkan satuan pendidikan tinggi tempat bertugas, serta memiliki kemampuan untuk mewujudkan tujuan pendidikan nasional.

Dosen harus memiliki kualifikasi akademik yang diperoleh melalui pendidikan tinggi program pascasarjana yang terakreditasi sesuai dengan bidang keahlian, minimum: Lulusan program magister untuk program diploma atau program sarjana Lulusan program doktor untuk program pascasarjana. Sertifikat pendidik adalah bukti formal sebagai pengakuan yang diberikan kepada dosen sebagai tenaga profesional, diberikan setelah memenuhi persyaratan sebagai berikut: Memiliki pengalaman kerja sebagai pendidik pada perguruan tinggi sekurangkurangnya 2 (dua) tahun; Memiliki jabatan akademik sekurang-kurangnya asisten ahli; dan Lulus sertifikasi yang dilakukan oleh perguruan tinggi terakreditasi yang menyelenggarakan program pengadaan tenaga kependidikan pada perguruan tinggi yang ditetapkan oleh Pemerintah RI.

Untuk memperoleh sertifikasi pendidik, maka dosen tersebut harus melalui uji kompetensi yang dilakukan dalam bentuk penilaian portofolio, yaitu merupakan penilaian pengalaman akademik dan profesional dengan menggunakan portofolio dosen. Penilaian portofolio dosen dilakukan untuk menentukan pengakuan atas kemampuan profesional dosen, dalam bentuk penilaian terhadap kumpulan dokumen yang mendeskripsikan: Kualifikasi akademik dan unjuk kerja tridharma perguruan tinggi; Persepsi dari atasan, sejawat, mahasiswa dan diri sendiri tentang kepemilikan kompetensi pedagogik, profesional, sosial dan kepribadian; dan Pernyataan diri tentang kontribusi dosen yang bersangkutan dalam pelaksanaan dan pengembangan tridharma perguruan tinggi.

\section{Dalam} melaksanakan tugas keprofesionalan, dosen berhak: memperoleh penghasilan di atas kebutuhan hidup minimum dan jaminan kesejahteraan sosial; mendapatkan promosi dan penghargaan sesuai dengan tugas dan prestasi kerja; memperoleh perlindungan dalam melaksanakan tugas dan hak atas kekayaan intelektual; memperoleh kesempatan untuk meningkatkan kompetensi, akses sumber belajar, informasi, sarana dan prasarana pembelajaran, serta penelitian dan pengabdian kepada masyarakat; memiliki kebebasan akademik, mimbar akademik, dan otonomi keilmuan; memiliki kebebasan dalam memberikan penilaian dan menentukan kelulusan peserta didik; dan memiliki kebebasan untuk berserikat dalam organisasi profesi/organisasi profesi keilmuan.

Dalam melaksanakan tugas keprofesionalan, dosen berkewajiban: melaksanakan pendidikan, penelitian, dan pengabdian kepada masyarakat; merencanakan, melaksanakan proses pembelajaran, serta menilai dan mengevaluasi hasil pembelajaran; 
meningkatkan dan mengembangkan kualifikasi akademik dan kompetensi secara berkelanjutan sejalan dengan perkembangan ilmu pengetahuan, teknologi, dan seni; bertindak objektif dan tidak diskriminatif atas dasar pertimbangan jenis kelamin, agama, suku, ras, kondisi fisik tertentu, atau latar belakang sosioekonomi peserta didik dalam pembelajaran; menjunjung tinggi peraturan perundang-undangan, hukum, dan kode etik, serta nilai-nilai agama dan etika; dan memelihara dan memupuk persatuan dan kesatuan bangsa.

Uraian tersebut merupakan bentuk kinerja dosen dalam rangka meningkatkan mutu lulusan yang siap kerja.

Berdasarkan data pelaksanaan tri dharma perguruan tinggi pada setiap universitas swasta dapat diketahui bahwa pada pelaksanaan pengajaran capaian mencapai $133 \%$ hal ini melebihi batas kewajiban dosen, kemudian pada bidang penelitian hanya mencapai $31,5 \%$ dan pengabdian hanya $27,5 \%$. Data ini menunjukkan bahwa rendahnya kinerja dosen dalam melaksanakan tugas tri dharmanya.

Permasalahan lainnya pada masalah kompensasi yang diterima dosen swasta dalam melaksanakan tugas tridharmanya, dimana dosen lebih senang mengajar karena kelebihan mengajar dari batas sks (sistem kredit semester) yang ditetapkan mendapatkan tambahan penghasilan, paling tinggi di UIR sebesar Rp. 60.000,- per sks dan yang terendah di UPP yakni Rp. 37.500. per sks. Kemudian untuk penelitian paling tinggi Rp. 3.000.000. dan paling rendah $\mathrm{Rp}$. 1.500.000. Juga untuk pengabdian paling tinggi Rp.2.500.000. dan paling rendah $\mathrm{Rp}$. 1.000.000,-, dosen kurang semangat dalam melaksanakan penelitian karena selain pekerjaannya rumit dan prosedurnya panjang kecenderungan dosen mendapatkan kompensasi yang relatif lebih rendah, apabila dibandingkan dengan biaya yang dikeluarkan tidak sebanding. Kemudian hal yang sama dirasakan dosen pada bidang pengabdian pada masyarakat, dimana masalah biaya menjadi kendala.
Jadi apakah sistem kompensasi atau pengupahan memberikan dampak terhadap kinerja dosen dalam melaksanakan tugas tri dharma perguruan tingginya.

Beberapa literature yang digunakan dalam penelitian ini antara lain menurut Kadarisman (2012: 11) kompensasi adalah apa yang seorang pegawai terima sebagai balasan dari pekerjaan yang diberikan. Baik upah per jam ataupun gaji periodik didesain dan dikelola oleh bagian sumberdaya manusia. Kompensasi yang diberikan ada yang berbentuk uang dan ada pula yang berbentuk tidak uang. Kompensasi yang berwujud upah pada umumnya berbentuk uang, sehingga kemungkinan nilai riilnya turun naik.

Menurut Handoko (2001:176) kompensasi merupakan penghargaan dalam bentuk finansial yang diberikan kepada mereka yang dapat bekerja melampui standar yang telah ditentukan. Istilah sistem pendapatan pada umumnya digunakan untuk menggambarkan rencana-rencana pembayaran upah yang dikaitkan baik secara langsung maupun tidak langsung dengan standar produktivitas karyawan. Karyawan yang bekerja dibawah sistem pendapatan berarti prestasi kerja mereka menentukan baik secara keseluruhan atau sebagian penghasilan mereka.

Selanjutnya oleh Moekijat (2001: 137) kompensasi dibedakan dengan gaji atau upah. Kompensasi adalah imbalan jasa yang diberikan kepada pegawai, karena yang bersangkutan telah memberikan sumbangan untuk mencapai tujuan organisasi. Dalam istilah kompensasi termasuk gaji, upah, perumahan pegawai, pakaian, tunjangan pangan dan tunjangantunjangan lainnya.

Menurut Teguh (2003: 208) tujuan kompensasi adalah:

1. Untuk memperoleh pegawai yang cakap Upah dan gaji harus cukup tinggi untuk menarik para pelamar. Tingkat pembayaran harus sesuai dengan permintaan dan penawaran

2. Untuk mempertahankan pegawaipegawai lama 
Apabila tingkat upah atau gaji rendah, maka beberapa pegawai akan berhenti dari pekerjaan. Untuk mencegah perpindahan pegawai maka tingkat pembayaran harus memadai

3. Untuk menjamin keadilan

Administrasi upah dan gaji berusaha mendapatkan keadilan internal dan eksternal. Keadilan internal adalah pekerjaan pekerjaan sama harus mendapat pembayaran yang sama pula. Keadilan eksternal adalah pembayaran pegawai pada suatu tingkat yang sama dengan pembayaran kepada pegawai pada suatu tingkat yang sama dengan pembayaran yang diperoleh pegawai tersebut dalam organisasi lain

4. Untuk menghargai perilaku yang diharapkan

Pembayaran harus memperkuat perilaku yang diharapkan . prestasi yang baik, pengalaman, kesetiaan, tanggung jawab baru dan perilaku yang lain dapat dihargai melalui rencana upah dan gaji yang efektif

5. Untuk mengendalikan biaya

Program upah dan gaji yang rasional membantu organisasi memperoleh dan mempertahankan tenaga kerjanya dengan biaya yang layak.

Dengan adanya kompensasi maka akan menunjang efektivitas organisasi. Efektivitas organisasi adalah kemampuan organisasi untuk memperoleh dan menggunakan sumber dayanya yang langka dan berharga itu dengan sebaik-baiknya untuk mencapai tujuan-tujuan operasional (Moekijat, 2001: 145-146).

Adapun fungsi kompensasi yang menunjang efektivitas organisasi adalah:

1. Kompensasi dapat dipergunakan untuk menarik pelamar-pelamar yang cakap bagi organisasi

2. Kompensasi membantu memperoleh pegawai-pegawai yang cakap dalam organisasi

3. Kompensasi dapat dipergunakan sebagai perangsang untuk memotivasi para pegawai memberikan usaha-usaha mereka yang terbaik

4. Mengurangi sebanyak-banyak biaya organisasi dapat juga menunjang keefektifan organisasi, karena kompensasi merupakan biaya yang penting bagi kebanyakan organisasi (Moekijat, 2001: 145-146)

Menurut Locke dalam dalam Widyastuty (2007: 22) menyatakan bahwa pendapatan berupa uang lebih dapat meningkatkan produktivitas dibandingkan dengan teknikteknik lainnya, seperti penetapan tujuan, partisipasi karyawan dalam pengambilan keputusan dan pemerkayaan pekerjaan (job enrichment). Adapun syarat-syarat yang patut dipenuhi dalam pemberian pendapatan agar tujuan pemberian pendapatan dapat diwujudkan sebagai berikut : Sederhana, peraturan dari sistem pendapatan haruslah singkat, jelas dan dapat dimengerti; Spesifik, karyawan perlu tahu dengan tepat apa yang diharapkan untuk mereka yang lakukan; Dapat dicapai, setiap karyawan seharusnya mempunyai kesempatan yang masuk akal untuk memperoleh sesuatu; Dapat diukur, sasaran yang dapat diukur merupakan dasar untuk menentukan rencana pendapatan.

Kemudian juga menurut Kadarisman (2012: 39) menjelaskan dimensi kompensasi adalah:

a. Tingkat kecukupannya sebagai imbalan dalam memenuhi kebutuhan dasar (kelayakan).

b. Bersifat wajar/adil dilihat dari sudut pasar tenaga kerja (eksternal organisasi/perusahaan)

c. Bersifat adil/wajar dan sudut kemampuan organisasi (internal organisasi/perusahaan)

d. Memperhatikan perbedaan untuk setiap pegawai organisasi/perusahaan berdasarkan kebutuhan individual, yang terkait dengan perbedaan posisi/jabatan, yang berarti perbedaan kewajiban dan tanggung jawab dalam keikutsertaan mewujudkan tujuan organisasi/perusahaan. 
Dari uraian tersebut, maka dapat dijelaskan kompensasi ialah suatu penerimaan sebagai suatu imbalan dari pemberian kerja kepada penerima kerja untuk suatu pekerjaan atau jasa yang telah dan akan dilakukan, berfungsi sebagai jaminan kelangsungan kehidupan yang layak bagi kemanusiaan. Dimensi kompensasi adalah sederhana, spesifik, dapat dicapai dan dapat diukur.

a. Kecukupan sebagai imbalan dalam memenuhi kebutuhan dasar (kelayakan).

b. Kewajaran dilihat dari sudut pasar tenaga kerja (eksternal organisasi)

c. Keadilan dari sudut kemampuan organisasi (internal organisasi) dalam memberikan pembayaran.

d. Memperhatikan perbedaan untuk setiap pegawai organisasi berupa kewajiban dan tanggung jawabnya.

Sedangkan kaitannya dengan kinerja, dibahas masalah kinerja dosen sebagai berikut menurut Tika (2005: 121) menyatakan kinerja sebagai hasil fungsi pekerjaan/kegiatan seseorang atau kelompok dalam suatu organisasi yang dipengaruhi oleh berbagai faktor untuk mencapai tujuan organisasi dalam periode waktu tertentu. Kemudian Lawler dan Porter dalam Sutrisno (2010: 170) menyatakan kinerja adalah kesuksesan seseorang dalam melaksanakan tugas. Kemudian menurut Miner dalam Sutrisno (2010: 170) menyatakan kinerja adalah bagaimana seseorang diharapkan dapat berfungsi dan berperilaku sesuai dengan tugas yang telah dibebankan kepadanya.

Widodo (2001: 47) bahwa kinerja adalah sesuatu yang dicapai, prestasi yang diperlihatkan dan kemampuan kerja. Kemudian menurut Mangkunegara, (2000: 67) istilah kinerja dari kata job performance atau actual performance (prestasi kerja atau prestasi, sesungguhnya yang dicapai seseorang). Pengertian kinerja adalah hasil kerja secara kualitas dan kuantitas yang dicapai oleh seseorang dalam melaksanakan tugasnya sesuai dengan tanggung jawab yang diberikan kepadanya. Selanjutnya dapat dipahami kinerja aparat mempengaruhi kinerja organisasi dimana dia berperan sebagai pelaku.

Menurut Soeprihanto (2000: 8), secara lebih rinci menyebutkan bahwa tujuan penilaian pelaksanaan pekerjaan (kinerja) sebagai berikut: 1) Mengetahui keadaan keterampilan dan kemampuan setiap pegawai secara rutin. 2) Untuk digunakan sebagai dasar perencanaan bidang personalia, khususnya penyempurnaan kondisi kerja, peningkatan mutu dan hasil kerja. 3) Dapat digunakan sebagai dasar pengembangan dan pendayagunaan pegawai seoptimal mungkin, sehingga antara lain dapat diarahkan jenjang karirnya atau perencanaan karir, kenaikan pangkat dan kenaikan jabatan. 4) Mendorong terjadinya hubungan timbal balik antara atasan dan bawahan. 5) Mengetahui kondisi organisasi secara keseluruhan dari bidang personalia, khususnya kinerja pegawai. 6) Secara pribadi pegawai dapat mengetahui kekuatan dan kelemahan masing-masing sehingga dapat memacu perkembangan. 7) Hasil evaluasi kinerja dapat bermanfaat bagi penelitian dan pengembangan di bidang personalia secara keseluruhan.

Peraturan Menteri Pendidikan Nasional Republik Indonesia No. 19 Tahun 2008 tentang perguruan tinggi penyelenggara sertifikasi dosen, dan Peraturan No. 20 Tahun 2008 tentang penetapan in passing pangkat dosen bukan pegawai negeri sipil yang telah menduduki jabatan akademik pada perguruan tinggi yang diselenggarakan oleh masyarakat dengan pangkat pegawai negeri sipil, telah membuat gairah para dosen khususnya di lingkungan perguruan tinggi swasta untuk memulai memperhatikan jenjang akademiknya. Karena jenjang akademik adalah merupakan salah satu bentuk penilaian pemerintah atas kinerja seorang dosen.

Bagi suatu perguruan tinggi, salah satu pihak yang berperan strategis dalam meningkatkan kemajuan dan kualitas lembaga tersebut adalah kinerja dosen (lecturer). Sejalan dengan pernyataan tersebut Khoe Yao Tung dalam Achmad Sanusi dan Sanusi Uwes dalam Muhardi (2004), menyatakan bahwa "Dosen 
merupakan faktor kunci sukses (key success factor) dari upaya untuk meningkatkan mutu jasa pendidikan". Pendapat yang sama dikemukakan oleh Abdurrachman dan S. Marten Yogaswara dalam Muhardi (2004:34) bahwa "Nilai keberhasilan pendidikan sangat tergantung dari mutu pengajarnya. Dosen adalah orang yang sangat berperan dalam proses belajar mengajarnya".

Dosen harus mempunyai beberapa kualifikasi yang diperlukan bagi pelaksanaan profesinya, mengingat profesi dosen berbeda dengan profesi bidang yang lain. Selain memerlukan ilmu pengetahuan juga harus menyampaikan ilmunya kepada mahasiswa. Dengan tenaga dosen yang mempunyai motivasi, berkompeten dan berkualitas akan memudahkan penyampaian ilmu pengetahuan dan teknologi sehingga apa yang disampaikan kepada mahasiswa dapat diterima dan dikembangkan sesuai dengan kemampuan mahasiswa dengan kajian bidang ilmu yang dipilihnya. Di samping itu dosen juga harus mempunyai komitmen yang tinggi yang ditunjukkan dengan kehadiran pada waktu kerja, juga mempunyai rasa tanggung jawab terhadap ilmu yang diberikan kepada mahasiswa.

Untuk mengetahui tinggi rendahnya kinerja dosen dalam melakukan pekerjaannya maka diperlukan adanya system penilaian terhadap kinerja dosen. Penilaian kinerja adalah suatu cara yang digunakan untuk mengukur pekerjaan yang dilakukan sesuai dengan target yang telah ditetapkan.

Sebagai tenaga professional, dosen yang bekerja dan menjalankan tugasnya, profesi juga perlakukan dilakukan penilaian dalam menjalankan pekerjaannya sebagai pendidik. Pentingnya penilaian kinerja dosen juga dikemukakan oleh Aiken Lewis R dalam Umi Narimawati (2005) "Bahwa penilaian terhadap kinerja dosen penting/ perlu dilakukan, mengingat dosen dalam posisi penting dalam mempengaruhi pelaksanaan pendidikan mahasiswanya maka tidak mengherankan apabila pemerintah, orang tua mahasiswa, serta yang lain memeprhatikan mutu pendidikan melalui kemampuan seorang dosen".
Menurut Ridwan (2011: 191) kinerja dosen adalah kualitas hasil kerja yang dilakukan dosen dalam pengajaran (proses belajar mengajar). Kesimpulan ini didasarkan pada konsep bahwa kinerja dosen adalah seperangkat perilaku yang ditunjukkan oleh dosen pada saat menjalankan tugas dan kewajibannya dalam bidang pengajaran dengan dimensi: kemampuan, prakarsa/inisiatif, ketepatan waktu, kualitas hasil kerja dan komunikasi.

Kemudian Ridwan (2011: 216) juga menjelaskan mengenai uraian dari masingmasing dimensi sebagai berikut:

a. Kemampuan yakni penguasaan materi dan penguasaan metode pengajaran.

b. Inisitif yakni berpikir positif yang lebih baik dan mewujudkan kreatifitas dan pencapaian prestasi.

c. Ketepatan waktu yakni pemanfaatan waktua kedatangan dan pemanfaatan waktu pulang.

d. Kualitas hasil kerja yakni kepuasan mahasiswa dan pemahaman mahasiswa serta prestasi mahasiswa.

e. Komunikasi yakni mutu penyampaian dan juga penguasaan keadaan kelas.

Sehubungan dengan penilaian kinerja, Craigh dalam Umi Narimawati (2005) mengidentifikasi sumber - sumber masalah dalam penilaian kinerja, yaitu; (a) competency problem, (b) motivational problem, dan (c) leadership and organizational problem. Dengan demikian kinerja seseorang sangat dipengaruhi oleh kompetensi yang dimiliki oleh setiap individu yang dilakukan evaluasi. Motivasi seseorang dalam melakukan tugas serta gaya kepemimpinan yang berlaku, aturan, dan lingkungann dari suatu organiasi tempat seseorang bekerja.

Berdasarkan pendapat tersebut di atas, jelas dapat dikatakan bahwa kinerja adalah suatu kumpulan total dari perilaku kerja yang ada pada pekerja, dalam kaitannya dengan kinerja dosen yaitu perilaku kerja dosen yakni dalam melaksanakan tri dharma perguruan tinggi yakni pengajaran, penelitian dan pengadian masyarakat. 
Menurut Robins (2001 : 273), bahwa: "Sejumlah faktor struktural menunjukkan suatu hubungan ke kinerja. Di antara faktor yang lebih menonjol adalah persepsi peran, norma, inekuitas status, ukuran kelompok, susunan demografinya, tugas kelompok dan kekohesifan (saling terkait)". Sedangkan menurut Mangkunegara (2002: 67) mengatakan bahwa faktor-faktor yang mempengaruhi kinerja pegawai adalah: 1) Faktor kemampuan dan 2) Faktor motivasi.

Kemudian faktor-faktor yang mempengaruhi kinerja pegawai, secara rinci dikemukakan oleh Mangkunegara (2002: 67) menyatakan bahwa setiap usaha untuk mengetahui mengapa seseorang berprilaku seperti yang dilakukan selama ini dalam organisasi memerlukan pemahaman tentang: (1) individu yang memiliki kemampuan, keterampilan mencakup mental dan fisik, latar belakang: keluarga, umur dan jenis kelamin, (2) organisasi meliputi : sumber daya, kepemimpinan, imbalan dan prosedur kerja, tim work dan (3) psikologi meliputi: persepsi, sikap, kepribadian dan motivasi serta komitmen. Lebih dari itu, adapun yang mempengaruhi faktor-faktor kinerja dalam suatu organisasi adalah faktor kemampuan dan faktor motivasi.

Berdasarkan uraian tersebut, maka dapat disimpulkan bahwa kinerja dosen adalah kualitas hasil kerja yang dilakukan dosen dalam pengajaran (proses belajar mengajar) dan juga sebagai seperangkat perilaku yang ditunjukkan oleh dosen pada saat menjalankan tugas dan kewajibannya dalam bidang pengajaran dengan dimensi: kemampuan, prakarsa/inisiatif, ketepatan waktu, kualitas hasil kerja dan komunikasi. Uraian dari masing-masing dimensi sebagai berikut:

a. Kemampuan yakni penguasaan materi dan penguasaan metode pengajaran.

b. Inisitif yakni berpikir positif yang lebih baik dan mewujudkan kreatifitas dan pencapaian prestasi.

c. Ketepatan waktu yakni pemanfaatan waktua kedatangan dan pemanfaatan waktu pulang. d. Kualitas hasil kerja yakni kepuasan mahasiswa dan pemahaman mahasiswa serta prestasi mahasiswa.

e. Komunikasi yakni mutu penyampaian dan juga penguasaan keadaan kelas.

\section{METODE}

Metode penelitian yang digunakan adalah metode kuantitatif. Sampel diambil dari populasi dosen swasta pada tiga perguruan tinggi yakni Universitas Islam Riau (UIR), Universitas Lancang Kuning (UNILAK) dan Universitas Pasir Pengaraian (UPP) di Fakultas Ekonomi Program Studi Akuntasni dan Manajemen yang berjumlah 68 orang yang terdiri dari UIR sebanyak 31 orang, UNILAK sebanyak 25 dan UPP sebanyak 12. Analisis data menggunakana persamaan regresi linier sederhana.

\section{HASIL}

Kinerja dosen adalah seperangkat perilaku yang ditunjukkan oleh dosen pada saat menjalankan tugas dan kewajibannya dalam bidang pengajaran dengan dimensi: kemampuan, prakarsa/inisiatif, ketepatan waktu, kualitas hasil kerja dan komunikasi. Bahwa kinerja dosen Prodi Manajemen dan Akuntansi dengan skor 3,04 atau 60,9\% masuk dalam kategori cukup baik.

Kompensasi ialah apa yang seorang pegawai terima sebagai balasan dari pekerjaan yang diberikan. Dimensinya: Kecukupan sebagai imbalan dalam memenuhi kebutuhan dasar (kelayakan); Kewajaran dilihat dari sudut pasar tenaga kerja (eksternal organisasi); Keadilan dari sudut kemampuan organisasi (internal organisasi) dalam memberikan pembayaran dan memperhatikan perbedaan untuk setiap pegawai organisasi berupa kewajiban dan tanggung jawabnya. Jawaban responden pada terhadap variabel kompensasi sekolah dengan skor 3.64 atau $72,9 \%$ masuk dalam kategori cukup bagus.

Uji secara individual ditunjukkan oleh tabel coefficients. Hipotesis penelitian yang akan diuji dirumuskan menjadi hipotesis statistik sebagai berikut:

Ha : $\rho y X>0$ 
Ho : $\rho y \mathrm{X}=0$

Hipotesis dalam bentuk kalimat:

$\mathrm{Ha}$ : Kompensasi berpengaruh secara signifikan terhadap kinerja dosen.

Ho : Kompensasi tidak berpengaruh secara signifikan terhadap kinerja dosen.

Secara individual uji statistik yang digunakan adalah uji $\mathrm{t}$ diperoleh niai $\mathrm{t}(\mathrm{X})=$ 8,992 . Terlihat bahwa pada kolom signifikan pada tabel coefficients sub-struktur 2 didapat nilai sig 0,000 . Nilai sig $0,000<0,05$, maka Ho ditolak dan Ha diterima, artinya kompensasi berpengaruh secara signifikan terhadap kinerja dosen.

\section{PEMBAHASAN}

Berdasarkan hasil perhitungan menunjukan bahwa kompensasi berpengaruh positif dan signifikan terhadap budaya organisasi. Besar kecilnya kontribusi kompensasi berdasarkan hasil perhitungan diperoleh nilai korelasi korelasi variabel kompensasi (X2) terhadap variabel budaya organisasi (X3) adalah sebesar 0,906 atau $($ ryx2 $=0,906)$. Hal ini menunjukkan hubungan yang kuat antara kompensasi dengan budaya organisasi. Sedangkan besarnya pengaruh kompensasi terhadap budaya organisasi ditunjukkan dengan koefisien regresi sebesar 0,372 , artinya jika variabel X1 tidak ada kenaikan nilai dari variabel kepemimpinan, maka setiap kenaikan nilai kompensasi satu satuan, maka nilai budaya organisasi bertambah sebesar 0,372 , karena pengaruh positif. Pengaruh variabel kompensasi ini juga signifikan karena angka sig sebesar 0,000 atau lebih kecil dari 0,05.

Pengaruh kompensasi terhadap budaya organsiasi berkaitan dengan apa yang seorang pegawai terima sebagai balasan dari pekerjaan yang diberikan, kecukupan sebagai imbalan dalam memenuhi kebutuhan dasar (kelayakan), kewajaran dilihat dari sudut pasar tenaga kerja (eksternal organisasi), keadilan dari sudut kemampuan organisasi (internal organisasi) dalam memberikan pembayaran dan memperhatikan perbedaan untuk setiap pegawai organisasi berupa kewajiban dan tanggung jawabnya.
Salah satu bentuk dari kompensasi yang membentuk budaya organisasi kondusif adalah dosen mendapatkan honor dalam melaksanakan kegiatan bimbingan skripsi mahasiswa sehingga kampus menjadi tempat menimba ilmu. Kemudian juga hal yang membuat kompensasi kurang mendukung budaya organisasi adalah dosen kurang mendapatkan gaji yang cukup untuk memenuhi kebutuhan hidup keluarga sehingga kurang tampak budaya membaca di kampus dan kurangnya kegiatan debat dalam rangka mencari solusi, karena dosen sibuk dengan urusan di luar kampus untuk mencari tambahan kebutuhan keluarga.

Hasil peelitian yang menarik menunjukkan bahwa:

a. Kecukupan sebagai imbalan dalam memenuhi kebutuhan dasar (kelayakan) dalam mendapatkan gaji yang cukup untuk memenuhi kebutuhan keluarga sudah mencukupi, kemudian sudah cukup mendapatkan tambahan penghasilan dari jabatan yang diemban dan sudah cukup mendapatkan insentif setiap melaksanakan tugas tambahan, serta mendapatkan honor dalam melaksanakan kegiatan bimbingan skripsi mahasiswa dan mendapat penghargaan dari hasil kerja yang dilakukan. Sehingga hal ini berpengaruh pada kegiatan kampus yang kurang aktif dan juga dosen banyak yang mencari sampingan mengajar di tempat lain.

b. Kewajaran dilihat dari sudut pasar tenaga kerja (eksternal organisasi) berupa mendapatkan upah standar UMR, mendapatkan kompensasi berdasarkan kompetensi yang dimiliki, mendapatkan kepuasan dari kompensasi yang diperoleh, termotivasi bekerja dari kompensasi yang diberikan dan selalu berusaha meningkatkan kinerja dalam rangka menambah kompensasi sudah cukup wajar. Sehingga dosen selalu membanding-bandingkan apa yang telah mereka peroleh di tempat mereka bekerja dan mencari tempat yang lebih menjanjikan. 
c. Keadilan dari sudut kemampuan organisasi (internal organisasi) dalam memberikan pembayaran dinilai masih dalam kategori cukup dimana dosen sudah mendapatkan perlakuan yang adil dalam penggajian, semakin tinggi jabatan fungsional maka gaji yang diperoleh semakin besar, Dosen yang menjabat struktural mendapatkan tambahan penghasilan, semakin berat jabatan struktural yang diemban maka semakin besar tunjangan diperoleh, peningkatan penghasilan dapat dicapai dengan kerja keras. Sehingga muncul tuntutan dari dosen kepada lembaga untuk meningkatkan kompensasi yang mereka terima.

d. Memperhatikan perbedaan untuk setiap pegawai organisasi berupa kewajiban dan tanggung jawabnya yang selama ini sudah cukup dimana Lembaga memperhatikan beban kerja dosen dalam membagi mata kuliah, pembagian beban kerja menjadi diskusi di setiap semester oleh dosen bersama prodi, setiap dosen mendapatkan porsi yang sama dalam mengajar sesuai kemampuan, setiap dosen diperlakukan sama untuk mendapatkan kesempatan berkarir dan dosen yang lebih senior mendapatkan proporsi sesuai dengan kontribusinya. Sehingga sebagian dosen kurang aktif di kampus.

Dari uraian tersebut di atas, dapat diketahui bahwa kompensasi memberikan pengaruh positif dan signifikan terhadap budaya organisasi kampus. Hal ini sejalan dengan apa yang dikatakan Moekijat (2001: 145-146) bahwa dengan adanya kompensasi maka akan menunjang efektivitas organisasi. Efektivitas organisasi adalah kemampuan organisasi untuk memperoleh dan menggunakan sumber dayanya yang langka dan berharga itu dengan sebaik-baiknya untuk mencapai tujuan-tujuan operasional.

\section{SIMPULAN}

Kesimpulan yang dapat diambil dari penelitian ini adalah sebagai berikut, bahwa Kompensasi berpengaruh terhadap budaya organisasi pada Fakultas Ekonomi Prodi Akuntansi dan Manajemen. Dari hasil pengolahan data diketahui pengaruh kompensasi $\left(\mathrm{X}_{2}\right)$ terhadap budaya organisasi $\left(\mathrm{X}_{3}\right)$ sebesar 0,372 .

\section{DAFTAR RUJUKAN}

Kadarisman, 2012, Manajemen Kompensasi, PT. Rajagrafindo Persada, Jakarta.

Mangkunegara, 2002, Manajemen Sumber Daya Manusia Perusahaan., PT. Remaja Rosdakarya, Bandung.

Mathis, 2009, Manajemen Sumber Daya Manusia, Salemba Empat, Jakarta

Moekijat, 2001, Manajemen Personalia dan Sumber Daya Manusia. Mandar Maju, Bandung.

Muhardi, 2004, Pengaruh Pemasaran Internal Terhadap Kepuasan Dosen Tetap dan Komitmennya Pada Mutu Jasa Pendidikan, Serta Implikasinya Terhadap Mutu Layanan Kepada Mahasiswa

Mulyasa, 2006, Manajemen Berbasis Sekolah Konsep, Strategi dan Implementasi, Bandung : PT. Remaja Rosdakarya

Natassia Ayudiarin, 2012, Pengaruh Iklim Organisasi Dan Pengembangan Karir Terhadap Kepuasan Kerja

Pabundu Tika, 2010, Budaya Organisasi dan Peningkatan Kinerja Perusahaan, Bumi Aksara, Jakarta.

Pamudji, 2005, Kepemimpinan Pemerintahan Indonesia, Jakarta: Bumi Aksara.

Pangabean, 2004, Manajemen Sumber Daya Manusia. Galia Indonesia, Bogor 
Peraturan Menteri Pendidikan Nasional Republik Indonesia No. 19 Tahun 2008 tentang perguruan tinggi penyelenggara sertifikasi dosen

Peraturan No. 20 Tahun 2008 tentang penetapan in passing pangkat dosen bukan pegawai negeri sipil

Purwanto, 2010, Administrasi dan Supervisi Pendidikan, PT. Remaja Rosdakarya, Bandung

Ridwan, 2011, Cara Menggunakan dan Memaknai Path Analysis, Alphabeta, Bandung

Robbins, 2008, Perilaku Organisasi, Terjemahan Tim Indeks. Indeks Garamedia, Jakarta.

Siagian, 2008, Manajemen Sumber Daya Manusia, Bumi Aksara, Jakarta.

Soeprihanto, 2000, Responsivitas dan Akuntabilitas Sektor Publik, Dalam Jurnal Administrasi Negara (Volume 1 No. 2 Maret 2001), FIA Unibraw, Malang.

Sopiah, 2008, Perilaku Organisasional, Andi, Yogyakarta.

Sutrisno, 2010, Budaya Organisasi, Kencana Prenada Media Group, Jakarta.

Teguh, 2003, Manajemen Sumber Daya Mausia, Konsep, Teori dan Pengembangan dalam Konteks Organisasi Publik, Graha Ilmu, Yogyakarta.

Teman Koesmono, 2005, Pengaruh Budaya Organisasi Terhadap Motivasi Dan Kepuasan Kerja Serta Kinerja Karyawan Pada Sub Sektor Industri Pengolahan Kayu Skala Menengah Di Jawa Timur
Tika, 2005, Budaya Organisasi dan Peningkatan Kinerja Perusahaan, Bumi Aksara, Jakarta.

Umi Narimawati, 2005, Pengaruh Kecocokan Kerja, Kepuasan Kerja, dan Komitmen Organisasional Terhadap Intensi Keluar Dosen dan Kinerja Dosen

Wahyudi, 2009, Meningkatkan Kinerja BUMN: Antisipasi Terhadap Kompetensi dan Deregulasi, Yogyakarta: JKAP No1

Wibowo, 2008, Manajemen Kinerja, Rajawali Press, Jakarta.

Widyastuty, 2007, Pengaruh Insentif terhadap Prestasi Kerja Pegawai, Tesis, UNAIR.

Wirawan, 2008, Budaya dan Iklim Organisasi Teori Aplikasi Penelitian, Salemba Empat, Jakarta. 